\title{
ENTERIC BACTERIA IN FECAL SAMPLES OF EURASIAN GRIFFON VULTURES
}

\author{
Dubravka Milanov", Dragan Fabijan², \\ Bojana Prunić ${ }^{1}$, Maja Velhner ${ }^{1}$, Tamaš Petrović ${ }^{1}$ \\ ${ }^{1}$ Scientific Veterinary Institute „Novi Sad“, Novi Sad, Republic of Serbia \\ ${ }^{2}$ Bird Study and Protection Society of Serbia, Novi Sad, Republic of Serbia
}

\section{Abstract}

Fecal samples originating from 15 Eurasian griffon vultures were collected during June 2012 in the territory of special nature reservation Uvac and examined for presence of enteric bacteria Escherichia coli and Salmonella spp. Salmonellas were isolated from five samples (33.3\%) and serologically typed as Salmonella enterica subsp. enterica ser. Veneziana. E. coli was isolated from four samples (26.6\%). Antimicrobial susceptibility testing revealed resistance to one and more antibiotics only in $E$. coli isolates.

Keywords: Escherichia coli, Salmonella Veneziana, Eurasian griffon vultures, antimicrobial resistance

\section{ENTERIČNE BAKTERIJE IZOLOVANE IZ UZORAKA FECESA EVROAZIJSKIH BELOGLAVIH SUPOVA}

\section{Dubravka Milanov ${ }^{1}$, Dragan Fabijan ${ }^{2}$,} Bojana Prunić ${ }^{1}$, Maja Velhner ${ }^{1}$, Tamaš Petrovićc

${ }^{1}$ Naučni institut za veterinarstvo „Novi Sad“, Novi Sad, Republika Srbija

${ }^{2}$ Društvo za zaštitu i proučavanje ptica Srbije, Novi Sad, Republika Srbija

\section{Kratak sadržaj}

Uzorci fecesa od 15 beloglavih supova sakupljeni su u junu mesecu 2012 na teritoriji specijalnog rezervata Uvac i bakteriološki ispitani na prisustvo bakterija iz rodova Salmonella i Echerichia coli. Salmonele su izolovane iz pet uzoraka fecesa, a svi izolati serološki tipizirani kao Salmonella enterica subsp. enterica ser. Veneziana. Escherichia coli je izolovana iz 4

\footnotetext{
${ }^{1^{*}}$ e-mail: dubravka@niv.ns.ac.rs
} 
uzorka. Izolovani sojevi enteričnih bakterija ispitani su na osetljivost prema antibioticima, a rezistencija na jedan ili više antibiotika je ustanovljena kod tri izolata E. coli.

Ključne reči: Escherichia coli, Salmonella Veneziana, evroazijski beloglavi sup, rezistencija na antibiotike

\section{Introduction}

Wild birds play an important role in the ecology and circulation of human and animal pathogens including viruses, bacteria, fungi and protozoa (Hubalek, 2004; Abulreesh et al., 2007; Benskin et al., 2009). In some European countries, wild birds (particularly gulls) are identified as reservoirs of enteric pathogens such as various serotypes of Salmonella (Kapperud et al., 1998; Hubalek, 2004; Čižek et al., 2007) and toxin-producing Escherichia coli strain (Abulreesh et al., 2007), which could be also multiple resistant (Palmgren et al., 2006; Čižek et al., 2007; Dolejska et al., 2007). Prevalence of salmonellosis among the wild-bird population has shown increasing tendency over the past 40 years as a result of artificial feeding by humans (Tizard, 2004). Wide range of Salmonella serotypes was isolated in wild birds, including multidrug-resistant strains of S. Typhimurium DT 104 (Reche et al., 2003; Čižek et al., 2007). Enteric pathogens mainly reside in the intestinal tract of raptors or opportunistic carrion eating birds (such as vultures, crows and gulls), who feed on the ground, at sites where human waste is released or live by the fecally contaminated waters (Gerlach 1994; Tizard, 2004, Palmgren et al, 2006; Kocijan et al., 2009). Both Salmonella and E. coli can be pathogenic for birds; however, more frequently, the birds are potential healthy carriers and play a role in the dissemination of the agents in the environment by contaminating the natural waters and animal feed (Palmgren et al., 2006; Cižek et al., 2007). Though their role in the epidemiology of salmonellosis is still debated, several studies have confirmed the possibility that wild birds could serve as the source of human infection (Millan et al., 2004, Kruse et al., 2004).

Eurasian griffon vultures (Gyps fulvus) are at the top of the food chain and play an essential role in the nature as they feed exclusively on carcasses of dead animals. The species inhabits the regions of Southern Europe, Southwestern Asia and North Africa. During the '90s of the last century, the survival of this species was critically endangered. Decrease in Eurasian griffon vulture population is closely associated with abandoning of extensive livestock breeding in the area and thus food scarcity, poisoning (Sabočanec et al., 2005) and laying poisoned baits for large predators (Pavoković, 2005) as well as the EU Regulations on mandatory carcass disposal 
aimed at prevention of Bovine Spongiform Encephalopathy. Limitation of natural habitat and reduced availability of their natural prey in our country resulted in changes of feeding habits of Eurasian griffon vultures. The diet of these wild birds is based mainly on slaughterhouse waste from intensive farming systems. Such diet could contribute to alterations of common microflora of the digestive tract. The available literature data on bacteriological examination Eurasian griffon vulture samples are still sparse both in the territory of Balkans and at a global level (Milan et al., 2004; Sabočanec et al., 2005; Kocijan et al., 2009). The aim of our study was to investigate presence of enteric bacteria in fecal samples (Escherichia coli and Salmonella spp.), which are not considered as a part of common intestinal microflora of Eurasian griffon vultures, and to examine the antibiotic susceptibility of these bacterial isolates.

\section{Materials and methods}

\section{Sample collection}

Location: Uvac River canyon valley with its three lakes (Uvačko, Zlatarsko and Radoinjsko Lake) as a Special Nature Reserve is protected natural asset of great importance according to the Decree of the Government of the Republic of Serbia („Official Gazette of the RS“ No. 25/06 and 110/06). It occupies some 7500 ha between mountain Zlatar massif in the Southwest and mountain Javor in the Northeast. The estimated population of griffon vultures in this reservation is currently around 100 nesting couples, and total population (including young birds) is some 300 birds. The adult nesting birds mostly do not leave their natural habitat, whereas young birds migrate during winter months to the north (via Slovenia and Italy to the Alps), to the south (Bulgaria, Greece, Israel and Africa) and to the west (France and Spain). 


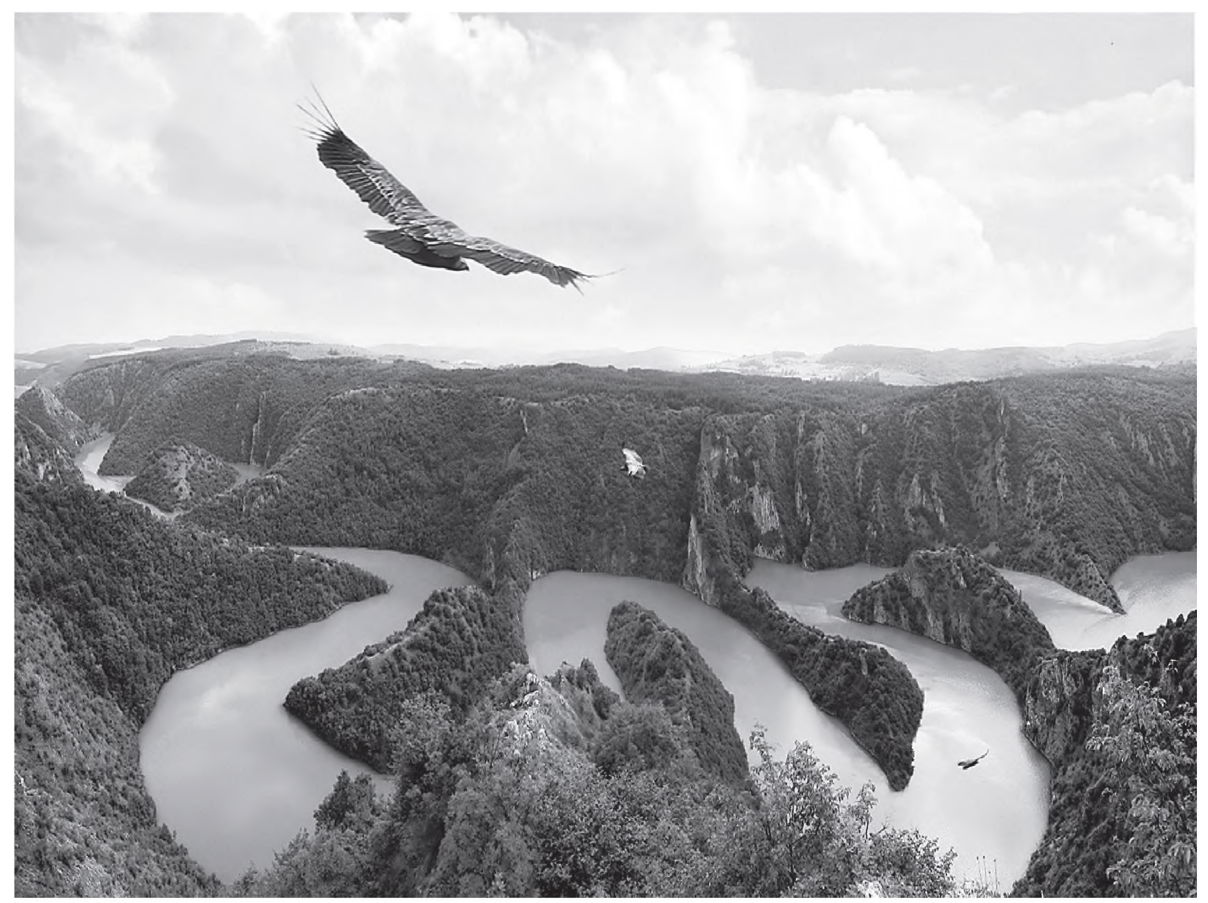

„The magnificent Uvac valley“, natural habitat of Eurasian griffon vulture (http:// www.politika.rs/rubrike/putovanja/U-carstvu-beloglavog-supa.lt.html)

Sampling was carried out at Uvac natural reservation in June 2012, during early morning hours. At the moment of sampling, around 50 Eurasian griffon vultures were present at the selected location. According to observation results, the birds were in good health condition. Fifteen fresh fecal samples were collected using sterile swabs. The samples were cooled and transported to the laboratory of clinical microbiology of the Scientific Veterinary Institute „Novi Sad".

\section{Microbiology examination}

Isolation of E. coli and Salmonella spp.:

Collected fecal swabs were inoculated into $2 \mathrm{~mL}$ peptone water (Buffered peptone water, CM1049, Oxoid, Basingstoke, UK) and vortexed for $30 \mathrm{sec}$ at maximum rpm. For the isolation of E.coli, $30 \mu \mathrm{L}$ of suspension was inoculated onto the Columbia blood agar base (CM0331, Oxoid) with 5\% sterile defibrinated sheep blood and MacConkey agar (CM0007, Oxoid). Inoculated plates were incubated at $37^{\circ} \mathrm{C}$ during $24-48 \mathrm{~h}$. Colonies of the characteristic appearance for the Enterobacteriaceae, were subcultivated on nutrient agar (CM0003, Oxoid). The colonies were examined using catalase and oxidase test and biochemical series test: "IMViC" (indole - methyl red-Voges Proskauer-citrate). 
Isolates that resulted $+/+/-/$ - on the "IMViC" test were further examined using BBL Crystal Enteric/Nonfermenter test (Becton Dickinson, Detroit, MI, USA). Isolation of Salmonella spp. was performed according to the protocol follow the ISO-6579: 2002 standard (Annex D), and biochemical confirmation of the isolates according to ISO 6579:2008 (9.5.3). Verification and serological typing of Salmonella isolates was performed in the National Reference Laboratory for Salmonella, Shigella, Vibrio cholerae, Yersinia enterocolitica, Institute of Public Health of Serbia "Dr Milan Jovanovic Batut", Beograd, Serbia.

Antibiotics susceptibility test:

Susceptibility of Salmonella and Escherichia coli isolates was examined by the disc diffusion method using Mueller-Hinton agar (CM337, Oxoid, Basingstoke, UK) according to Clinical and Laboratory Standards recommendation (document M100-S22, CLSI, 2012). The following antibiotics were tested: amoxicillin + clavulanic acid $(20 / 10 \mu \mathrm{g})$, ampicillin $(10 \mu \mathrm{g})$, cefpodoxime (10 $\mu \mathrm{g})$, ceftazidime $(30 \mu \mathrm{g})$, cefotaxime $(30 \mu \mathrm{g})$; ciprofloxacin $(5 \mu \mathrm{g})$, chloramphenicol $(30 \mu \mathrm{g})$, gentamicin $(10 \mu \mathrm{g})$, nalidixic acid $(30 \mu \mathrm{g})$, streptomycin $(10 \mu \mathrm{g})$, sulphonamides $(300 \mu \mathrm{g})$, tetracycline $(30 \mu \mathrm{g})$, trimethoprim $(5 \mu \mathrm{g})$, trimethoprim + sulfamethoxazole $(1,25 / 23,75 \mu \mathrm{g}$ ) (antimicrobial susceptibility discs Bio-Rad Laboratories, France). The plates were incubated for $18 \mathrm{~h}$ at $37^{\circ} \mathrm{C}$.

\section{Results AND Discussion}

In the ' 90 s of the last century, the griffon vulture population in the Republic of Serbia was threatened by extinction. In the territory of Uvac-lakes, there were only seven individuals of this rare species from the Accipitridae family. The survival of this endangered species was enabled through continual delivery of slaughterhouse waste (some 50 tons per year). Nowadays, Uvac is the largest colony of this unique bird species in the Balkans, and among the large ones in Europe. Diet based on animal carcasses, i.e. sheep, bovine and horses from intensive farming systems, undoubtedly contributed to the survival of griffon vultures; however, feeding slaughterhouse waste could negatively affect the health of avian scavengers and promote transmission and spread of bacteria from these sources (Blanco et al., 2006).

In this research, bacteria of the genus Salmonella were isolated from five (33.3\%) fecal samples originating from Eurasian griffon vultures. All isolates fermented glucose, produced $\mathrm{H} 2 \mathrm{~S}$ and L-lysine decarboxylase. Negative reactions were obtained for Voges Proskauer and indole tests, lactose fermentation, production of $\beta$-galactosidase (ONPG) and urease. In the national Reference Laboratory for Salmonella, Shigella, Vibrio cholerae, Yersinia enterocolitica, all isolates were serotyped as Salmonella enterica subsp. enterica ser. Veneziana 
(11: i: e, $\mathrm{n}, \mathrm{x}$ ). This Salmonella serotype was first isolated from an apparently normal Italian civilian food handler in Venice, Italy, and described as a new serotype in 1945 (Bruner et al., 1945). S. Venezianae is not listed among the 15 most frequently isolated serotypes in Serbia (www.who.int/gfn). According to the available literature, data on isolation of this serotype are scanty. In the period 1998-2008 in the U.S., only one case of laboratory-confirmed isolation of this serotype in humans was reported (CDC, 2008). S. Venezianae was isolated from mesenteric lymph nodes of one horse out of 500 examined samples taken from 100 slaughtered healthy horses (Bonardi et al., 1997). Disc diffusion test with $\mathrm{S}$. Veneziana isolates did not reveal resistance against antibiotics used in the experiment.

The birds are generally considered as healthy carriers of Salmonella (Mikaelian et al., 1997; Milan et al., 2004), since their isolation is usually not associated with symptoms of the disease (Palmgren et al., 2006) nor macroscopic or microscopic lesions characteristic for salmonellosis (Milan et al., 2004). Epizootic outbreaks of salmonellosis in raptors are extremely rare as compared to other bird species (Milan et al., 2004). The incidence of one particular serotype indicates the existence of one same infection source or possibility of specific adaptation of Salmonella to the host, when it establishes itself as a part of the intestinal flora (Tizard, 2004). In free living raptors, examination of fecal samples revealed mainly low incidence of salmonellas, being $1.5 \%$ (Skov et al., 2008) , 1.9\% (Mikaelian et al., 1997) and 4.19\% (Reche et al. 2003). Within the framework of large-scale investigation of salmonellosis in wild animals, Milan et al. (2004) established a prevalence of $8.5 \%$ (7/82) in wild birds, while S. Typhimurium was isolated in one, out of three examined fecal sample originating from Eurasian griffon vultures.

Bacteriological examination of fecal samples in this research revealed presence of Escherichia coli in four (26.6\%) samples. Kocijan et al. (2009) performed bacteriological, mycological and parasitological analysis of fecal samples $(\mathrm{n}=10)$ and vomit samples $(\mathrm{n}=5)$ of griffon vultures from the island Cres, Croatia. Escherichia coli was the most frequent bacterial isolate in both sample categories (feces 9/10, vomit samples 2/5). In raptors, Escherichia coli can be associated with diverse pathologic lesions (bumble foot, pericarditis, hepatic abscesses, salpingitis, and egg peritonitis) (Morishita et al., 1997). However, the virulence factors of particular E.coli strains, which are of importance in humans and mammals, do not accurately predict the relative importance of the strains for birds (Gerlach, 1994). In this research, one E. coli isolate manifested multiple-resistance to streptomycin, tetracycline, amoxicillin+clavulanic acid, ampicillin and trimethoprim/sulfamethoxazole, whereas two isolates were resistant to 
ampicillin. The reports on bacteriological examination of samples originating from Eurasian griffon vultures are extremely limited (Milan et al., 2004; Sabočanec et al., 2005; Kocijan et al., 2009), whilst data on antibiotic susceptibility of bacterial isolates are still lacking.

Undoubtedly, humans play an important role in spreading pathogens among the wild bird population through contamination of waters by sewage waste, inadequate waste management and by artificial feeding of birds. Predominance of enteric bacteria and antibiotic-resistant strains within the population of griffon vultures, as well as their role in survival and spread of such bacteria in the natural environment remains unclear. Transmission of bacteria from birds to mammals requires repeated exposure and large numbers of microorganisms (Gerlah, 1994), thus the importance of Eurasian griffon vultures as a source of human and animal infection is not significant, which is due to the "solitary lifestyle" of these birds in inaccessible terrain. However, as feeding ecology is the principal factor that influences exposure of birds to intestinal bacteria (Benskin et al., 2009), the diet of griffon vultures based on slaughterhouse waste might have some negative impact upon health status of these birds and spreading of resistant strains of enteric bacteria over large distances by young migrating birds.

\section{Acknowledgment}

This work is supported by a grant from the Ministry of Education, Science and Technological Development, Republic of Serbia, Project number TR 31084.

\section{LITERATURA}

1. Albureesh H.H., Goulder R., Scott G.W.: Wild birds and human pathogens in the context of ringing and migration. Ringing \& Migration, 23, 193-200, 2007.

2. Benskin C.M., Wilson K., Jones K., Hartley I.R.: Bacterial pathogens in wild birds: a review of the frequency and effects of infection. Biol Rev, 84, 349-373, 2009.

3. Blanco G., Lemus J.A., Grande J.: Faecal bacteria associated with different diets of wintering red kites: influence of livestock carcass dumps in microflora alteration and pathogen acquisition. J Appl Ecol, 43, 990-998, 2006.

4. Bonardi S., Bottarelli A., Bentley S., Poeta A., Alberti C.A.: Isolation of Salmonella typhimurium and Salmonella veneziana from slaughtered horses. Atti della Societa Italiana delle Scienze Veterinarie, 51, 703-704, 1997. 
5. Bruner D.W., Captain V.C., Joyce B.J.: Salmonella Veneziana - a new type. Veterinary Section of the 15th Medical General Laboratory, 1945.

6. Centers for Disease Control and Prevention, National Salmonella Surveillance System, Annual Summary, 2008.

7. Clinical and Laboratory Standards Institute, Performance standards for antimicrobial susceptibility testing; Twenty-second informational supplement. Clinical and Laboratory Standards Institute document M100-\$22. CLSI, Wayne, Pa, USA, 2012.

8. Dolejska M., Cižek A., Literak I.: High prevalence of antimicrobial-resistant genes and integrons in Escherichia coli isolates from black-headed gulls in the Czech Republic. J Appl Microbiol, 103, 11-19, 2007.

9. Cižek A., Dolejska M., Karpiškova R., Dedičova D., Literak I.: Wild blackheaded gulls (Larus ridibundus) as an environmental reservoir of Salmonella strains resistant to antimicrobial drugs. Eur J Wildlife Res, 53, 55-60, 2007.

10. Gerlach H.: Disease etiologies: Bacteria, in: Avian medicine: principles and application, Section five, Chapter 33, Wingers Publishing, Inc., Lake Worth, Florida, pp. 949-965, 1994.

11. Hubalek Z.: An annotated checklist of pathogenic microorganisms associates with migratory birds. J Wildlife Dis, 40, 639-659, 2004.

12. International Organization for Standardization, Geneve, Switzerland, ISO 6579:2002, Microbiology of food and animal feeding stuffs - Horizontal method for the detection of Salmonella spp. - Amendment 1: Annex D: Detection of Salmonella spp. in animal faeces and in environmental samples from the primary production stage (ISO 6579:2002/Amd 1:2007).

13. Kapperud G., Stenwig H., Lassen J.: Epidemiology of Salmonella Typhimurium O:4-12 infection in Norway: evidence of transmission from an avian wildlife reservoir. Am J Epidemiol, 147, 774-782, 1998.

14. Kocijan I., Prukner-Radovčić E., Beck R., Galov A., Marinculić A., Sušić G.: Microflora and internal parasites of the digestive tract of Eurasian griffon vultures (Gyps fulvus) in Croatia. EurJ Wildlife Res, 55, 71-74, 2009.

15. Kruse H., Kirkemo A.M., Handeland K.: Wildlife as source of zoonotic infections. Emerg Infect Dis, 10, 2067-2072, 2004.

16. Mikaelian I., Daignault D., Duval M.C., Martineau D.: Salmonella infection in wild birds from Quebec. Can Vet J, 38, 385, 1997.

17. Millán J., Aduriz G., Moreno B., Juste R.A., Barral M.: Salmonella isolates from wild birds and mammals in the Basque Country (Spain). Rev sci tech Off int Epiz, 23, 905-911, 2004.

18. Morishita T.Y., Aye P.P., Brooks D.L.: A survey of diseases of raptorial birds. J Avian Med Surg, 11, 77-92, 1997. 
19. Palmgren H., Aspan A., Broman T., Bengtsson K., Blomquist L., Bergstrom S., Sellin M., Wollin R., Olsen B.: Salmonella in Black-headed gulls (Larus ridibundus); prevalence, genotypes and influence on Salmonella epidemiology. Epidemiol Infect, 134, 635-644, 2006.

20. Pavoković G., Sušić G.: Poisoning of 17 Eurasian Griffons by carbofuran on the Island of Rab, Croatia, in December 2004. Vulture News, 53, 24-25, 2005.

21. Reche M.P., Jimenéz P.A., Alvarez F., García de los Rios J.E., Rojas A.M., de Pedro P.: Incidence of salmonellae in captive and wild free-living raptorial birds in central Spain. J Vet Med B Infect Dis Vet Public Health, 50, 42-44, 2003.

22. Sabočanec R., Konjević D., Srebočan E., Petrinec Z.: Fatal poisoning of a Griffon vulture (Gyps fulvus) with methomyl. Eur J Wildlife Res, 51, 210 212, 2005.

23. Skov M.N., Madsen J.J., Rahbek C., Lodal J., Jespersen J.B., Jørgensen J.C., Dietz H.H., Chriél M., Baggesen D.L.: Transmission of Salmonella between wildlife and meat-production animals in Denmark. J Appl Microbiol, 105, 1558-1568, 2008.

24. Tizard I.: Salmonellosis in Wild Birds, Seminars in avian and exotic pet medicine. 13, 50-66, 2004.

Received / Primljeno: 15.10.2013. Accepted / Odobreno: 08.12.2013. 